\title{
THE USE OF REQUEST STRATEGIES OF INDUSTRIAL ENGINEERING STUDENTS
}

\author{
Yoga Prihatin \\ Department of English Education, Universitas Pancasakti Tegal, Indonesia \\ E-mail: yogaprihatin@yahoo.com \\ Nur Aflahatun \\ Department of English Education, Universitas Pancasakti Tegal, Indonesia \\ E-mail: nuraflahatun@gmail.com
}

\begin{abstract}
APA Citation: Prihatin, Y., \& Aflahatun, N. (2020). The use of request strategies of industrial engineering students. English Review: Journal of English Education, 8(2), 227-236. doi: 10.25134/erjee.v8i2.1994.
\end{abstract}

\begin{abstract}
The aim of this study is to investigate the types of the request strategy used by Industrial Engineering students as EFL learners. Using qualitative data, this study discusses the use of request strategy in case-based teaching of foreign languages. The participants of the study are 37 Industrial engineering students who learnt English in the second semester. The testing instruments used were discourse completion task. For this aim, a discourse completion test was used to generate data related to the request strategies by each group. Selection of request situation in discourse completion test was based on three social factors of relative social distance, power, and rank of imposition. The participants' responses were analyzed according to the classifications of request strategy by Blum-Kulka \& Olshtain. The case study findings indicate that $57 \%$ of Industrial Engineering students' responses mostly use conventional indirect strategies, $29.2 \%$ responses are direct strategies, and $13 \%$ responses belong to non-conventional indirect strategies. $49.7 \%$ responses belong to query preparatory. $17.8 \%$ responses are identified as explicit performatives, $10.3 \%$ responses categorized as want statements, $9.2 \%$ responses classified as strong hints, $6.5 \%$ responses grouped as mild hints, $4.9 \%$ responses recognized as suggestive formulas, and $1.6 \%$ responses indicated as mood derivable. The indirectness is greatly influenced by students' cultural background, which belong to high-context culture. People in high context culture refer to the value cultures placing on indirect communication. A message is understood with a great deal of gesture, facial expressions, tone of voice, eye contact, body language, posture, and other ways people can communicate without using language. The findings of this study may set pedagogical implications for teachers, and learners of EFL therefore conducting a further field investigation is recommended to have in depth exploration about request strategies made by EFL Learners.
\end{abstract}

Keywords: industrial engineering students; request strategy; indirectness; direct strategies; high-context culture.

\section{INTRODUCTION}

The study of request speech act has been widely investigated by Wichmann (2004), Derakhshan \& Arabmofrad (2018), Saadatmandi, M., Modarres, S., and Pourdana (2018) Herget and Pérez (2019). The findings obtained in those studies help the teacher to concentrate overcoming problematic aspects in pragmatic, discover, and employ strategies and activities to improve students' pragmatic competence and solve difficulties in intercultural communication.

Other studies of the importance of explicit teaching of indirect strategies used in English requests also have been conducted (Al Aamri, 2014; Bitterlin, Johnson, Price, Ramirez, \& Savage, 2008; McCarthy, McCarten, \& Sandiford, 2014; Soars \& Soars, 2010). Following the previous studies and Blum-Kulka \& House as cited in Anhangari \& Shoghli (2011) shows that social/contextual variables in certain situations influence the speaker's speech directly or indirectly, this study focuses on the Indonesian learners' requests.

Due to the complexity of speech acts such as in the field of interlanguage pragmatics, Vásquez and Sharpless (2009) highlighted the importance of teaching pragmatics to EFL learners avoiding devotion made by EFL learners due to the complexity of speech acts such as request learned by L2 learners. The difficulty or deviation of certain speech acts is strongly influenced by social, cultural, situational, and personal factors of the speaker. These factors are actually quite important in shaping the end of the linguistic output of L2 students. 
To obtain the goals of communication and to promote pragmatic ability of EFL learners, it is necessary for the learners to understand speech acts, namely The use of request spoken in their utterances and find out strategies used by learners to achieve their communication purposes in different countries. By recognizing and understanding request strategy usage helping them to be more pragmatically and culturally aware of their own utterances (Hussein \& Albakri, 2019), therefore investigating request strategy used by Industrial Engineering learners in Indonesia enriches the references of pragmatic research. EFL learners may find similarity and differences among different countries in which English is taught as the foreign language.

Brown and Levinson in Yazdanfar \& Bonyadi (2016) stated request is the Face Threatening Acts (FTAs); because speakers impose their will on listeners. Brown and Levinson in Liu \& Allen (2014) propose, that facing the need to conduct an FTA, individuals must choose between conducting an FTA directly and efficiently and trying to reduce the effects of FTA on the listener's face. When the speaker's utterance is completed in a direct, clear, unambiguous, and concise way, he uses on record FTA, on the other hand when the utterance is ambiguous in order for the interactant to not be held responsible for a particular intention of a future act, off record strategy is used.

Requests can be expressed in a variety of ways with different types of strategies and levels of directness. The most well-known empirical study of cross-cultural pragmatics was the CrossCultural Speech Act Realization Project (CCSARP), by Blum-Kulka, House, and Kasper in (Daska which identified three levels of directness for 'request' speech actions: direct requests, conventional indirect requests, and nonconventional indirect request on social constraints, social distance and power, as well as on the level of imposition.

It is very challenging and interesting to know the way industrial engineering students of Universitas Pancasakti Tegal making requests from various situations provided in the discourse completion task. They should be EFL learners at the intermediate level since they have learned English since they were in Junior High School. This study analyzes 'request' strategies used by first-semester students of Industrial Engineering Universitas Pancasakti Tegal. Participants' responses were analyzed according to the classification of request strategies proposed by
Blum-Kulka et al. in Daskalovska, Ivanovska, Kusevska, \& Ulanska, 2016.

Learners are unable to master the target language without having language competence and this is the aim of language learning and teaching (Daskalovska, Ivanovska, Kusevska, \& Ulanska, 2016). Intercultural communication may not run well because of the different level of language competence in English language.

Request is one of speech acts used in communication. Making a request needs strategy so it will not cause misapprehension. Request strategy is compulsory choice of the level of directness in which the act of requesting is realized (Blum-Kulka et al. in Mohamed, 2019).

A request should be carefully made as misunderstanding may occur because of different cultural background. By making a request, the speaker violates on the recipient's freedom from imposition. Request imposes an intrusion or power play on the recipient's freedom. A requester also very often hesitates to make a request as recipient's lose face possibility takes place. Both the speakers and the recipient' face are at risks of face threatening acts of imposition on freedom of action (Brown and Levinson in Amer et.al, 2020). However, there are crucial sociological factors in establishing level of directness in making request such as power, social distance, and imposition to save face threating act in making request.

Avoiding or minimizing impositions, speakers of EFL learners tend to use more indirect request strategies resulting more polite requests and saving the recipients' face. Eslamirasekh in Deveci \& Hmida (2017) stated that each culture constructs a different set of difficulties for learners to improve their own strategies in applying the speech act of request in English language. There are three categories of directness of request strategies (Blum-Kulka \& Olshtain in Mohamed, 2019):

a) Direct strategies/explicit requests, such as imperatives:

Go to the room.

I'm asking you to go to the room.

I'd like to ask you to go to the room.

You'll have to go to room.

I really wish you'd go to the room.

b) Conventionally indirect strategies (referring to contextual preconditions necessary for its performance as conventionalized in the language):

How about going to the room?

Could you go to the room, please? 
c) Non-conventionally indirect strategies (hints) (partially referring to the object depending on contextual clues):

You have left your room dirty.

I'm a married. (In response to a persistent womanizer)

Communication is mostly performed without offending others wherever possible in Indonesia. Indirect communication mostly used by Indonesian as messages exchanged in a highcontext culture carry implicit meanings with more information than they did actually spoken parts. This condition affects EFL learners in Indonesia when using English as a means of communication. (Thomas in Yazdanfar \& Bonyadi, 2016) indirect request can be defined as politeness. Indonesians assume using indirect strategies make their request more interesting and resulting goals different from their partners, or when higher levels of politeness

The three directness levels of request strategies are further categorized into nine sublevels of request strategy types 'that form a scale of indirectness' (Table 1). The first five strategies are the direct level, the next two belong to the conventional indirect level, and the last two are the nonconventional indirect level.

Table 1. Request categories proposed by Blum-Kulka

\begin{tabular}{|c|c|c|c|}
\hline No & & Descriptive Categories & Examples \\
\hline 1. & $\begin{array}{l}\text { Direct } \\
\text { Strategies }\end{array}$ & $\begin{array}{l}\text { Mood Derivable } \\
\text { (the grammatical mood of the verb in the } \\
\text { utterance marks its illocutionary force } \\
\text { as request) }\end{array}$ & Leave me alone! \\
\hline 2. & & $\begin{array}{l}\text { Explicit Performative } \\
\text { (explicitly named by the speaker) }\end{array}$ & I'm asking you to leave alone. \\
\hline 3. & & $\begin{array}{l}\text { Hedged Performative } \\
\text { (Utterances embedding the naming of } \\
\text { the speaker's intention) }\end{array}$ & I would like to ask you to teach me. \\
\hline 4. & & $\begin{array}{l}\text { Obligation statement } \\
\text { (the intention point is direct) }\end{array}$ & You'll have to clean up the mess. \\
\hline 5. & & $\begin{array}{l}\text { Want Statement } \\
\text { (The utterance expresses the intention } \\
\text { of the speaker vice versa the fact that the } \\
\text { hearer does) }\end{array}$ & $\begin{array}{l}\text { I really wish you to marry me. } \\
\text { I really wish you to leave me alone. }\end{array}$ \\
\hline 6. & $\begin{array}{l}\text { Convention } \\
\text { ally indirect } \\
\text { strategies }\end{array}$ & $\begin{array}{l}\text { Suggestive Formulae } \\
\text { (The utterance contains suggestion) }\end{array}$ & $\begin{array}{l}\text { How about calling your advisor? } \\
\text { Why don't you come and discuss the } \\
\text { problems we have? }\end{array}$ \\
\hline \multirow[t]{2}{*}{7.} & & $\begin{array}{l}\text { Query Preparatory } \\
\text { (The utterance contains reference to } \\
\text { prepatory conditions } \\
\text { conventionalized in any specific } \\
\text { language) }\end{array}$ & Could you come to see me, please? \\
\hline & & & $\begin{array}{l}\text { Would you mind coming to see me, } \\
\text { please? }\end{array}$ \\
\hline 8. & $\begin{array}{l}\text { Non- } \\
\text { Convention } \\
\text { ally indirect }\end{array}$ & $\begin{array}{l}\text { Strong Hints }(\mathrm{A}) \\
\text { (The utterance has partial reference to } \\
\text { object for the implementation of the act). }\end{array}$ & You have left me without food to eat. \\
\hline 9. & strategies & $\begin{array}{l}\text { Mild Hints (B) } \\
\text { (Utterances do not refer but are } \\
\text { interpretable through the context as } \\
\text { requests). }\end{array}$ & The baby is crying. \\
\hline
\end{tabular}

Furthermore, Blum-Kulka and Olhstain in Daskalovska, et. al (2016) speaker has various strategies in mitigating request depending on request perspectives, syntactic and other downgraders and upgraders and adjuncts to the head act. Request perspectives categories are:

a. Speaker oriented (could I take you home?) b. Hearer oriented (could you make up your bedroom?)

c. Speaker-hearer oriented (could we finish the dispute?)

d. Impersonal (It may be a good idea to finish the dispute) 
Syntactic downgraders include:

a. The use of interrogatives (Could you go?),

b. Negation (Hi, I wonder if you wouldn't mind cleaning the room?)

c. The past tense (I wanted to ask for a cancelation)

d. Embedded 'if' clause (I would happy it if you took me home).

e. Consultative devices (Do you think I could borrow your lecture notes from yesterday?)

f. Understatements (Could you tidy up a bit before I start?),

g. Hedges (It would really help if you did something about the kitchen)

h. Downtoners (Will you be able perhaps to drive me?).

Communication style varies across cultures. People need to define the characteristics of both high context and low context culture in the interactions. Hall in Zhang (2019) speaker of high context culture often disguise the message they intend to deliver to keep harmonious relationship in the process of communication causing more miscommunication and misunderstanding especially when the communication occurs between the two person from different cultural background. On the other hand, speaker of low context culture expresses their message more dependently on context, and their intention need to be interpreted, and understood by the other side directly and clearly.

Indonesia is a country belongs to high context cultures, in which the social relationship, power, distance, and socio cultural norms impact on the way people talk each other stressing the aspect of cooperation in communication. Indonesians consider the superiority and inferiority of the elder and the younger, and peers should use the way of lowering themselves and honoring others in order to be polite. The communication relies on the hearer ability to read 'between the lines' what is being spoken or written. Meaning is not the intended message of the communicators. The hearers need to observe non-verbal behaviors. Facial expressions, the tone, and pitch of the voice, gestures, and the physical distance between the communicators must be well noticed to avoid misunderstanding in the interaction as message is very little coded, explicit, or transmitted part of the message in a high context communication. Jaliliafar (2009) concludes that the EFL learners at advanced level of language proficiency overused the indirect request strategies relative to the excessive use of direct request strategies by less proficient EFL learners.
Interruption is not highly likely to happen as communication in a linear way. It is indirect, ambiguous, and harmonious, reserved, and understated (Gudykunst and Ting-Toomey: 1988). High context culture speakers are not able to provide enough contextual information in their sentences and even in their body language to take every fact of what they do and say seriously when communicating with someone from a different background (Holliday, et. al, 2010). The hearer must be able to read the between the line to understand fully what the speaker's intention. The hearer needs his knowledge of speaker's cultural background to read between the lines because there are so many cultural influences involve in communication.

In a low context culture, as Hall in Zhang (2019) explains, communication style is very direct, clear, and straightforward. Meanings are explicitly stated giving little room for confusion or interpretation. Further explanation will be informed details to make up for what is missing in the context (both internal and external), when meaning negotiation stuck. Communication is a way of exchanging information, ideas, and opinions by using clear meaningful words. It is precise, dramatic, open, and based on feelings or true intentions based on trust builder relationship

It is easier to interpret the interaction of people in low context culture since they say what they mean to say. Implicit meaning is less used in the conversation, it does not need much effort to understand the speaker's intention minimizing misunderstanding between the speaker and the hearer.

\section{METHOD}

This case study aims to analyze the requests strategies made by students of Industrial engineering and to investigate the possible factors influencing the strategies related to literatures. The participants of the study are 37 Industrial Engineering students at intermediate level in Universitas Pancasakti Tegal. To collect the data, the participants were given task instruction in the form of Discourse Completion Tests (DCT) to investigate the extent of the learners' pragmatic competence in making requests. DCT is the most popular method deployed by researchers in interlanguage pragmatics despite some drawbacks (Brown, 2008).

Five situations were provided for participants in written DCT form based on social distance, level of power, and level of imposition. The given situations are listeners have a lower status, the 
listener has an equal status, or the listener has a higher status. The examples of distance are the other person knows each other, or they do not know each other, and the level of imposition can be low or high.

Participants' pragmatic competencies were challenged to use effective request strategies by means of the DCT. They had to write what they would say in the given context. Data was analyzed by using coding scheme, and crosscultural speech acts (CCSARP). The schematized CCSARP request strategy covers three categories: direct, conventional indirect and indirect nonconventional which are further elaborated as a nine-point scale. The data accumulated through DCT were analyzed and categorized according to the type and frequency of the strategies used by students.

\section{DCT Instruments}

This study used Discourse Completion Task (DCT) in eliciting students' request strategy. The task describes the setting and situation including the information of social distance, relative power and the degree of imposition between the participants in the scenario. The students completed the five given situation below by creating a dialogue of request strategies for each situation;

Situation 1
Create a dialogue of request to a person of superior status.

You meet your lecturer in his office and ask his permission to have make-up test.

\section{Situation 2}

Create a dialogue of request to a person friend (equal status)

You ask your friends to help you doing group assignment.

Situation 3

Create a dialogue of request to a friend (equal status).

You have a new friend on Facebook. You ask him to meet up in person.

\section{Situation 4}

Create a dialogue of request to a person of superior status

You ask your parents to give you money for university tuition.

Situation 5

Create a dialogue of request to a stranger.

You meet a stranger at the street and ask him the direction to hospital.

\section{RESULTS AND DISCUSSION}

Categories of directness of request strategies

The following table is the type of request strategies and the frequencies of request strategy occurrence used by Industrial Engineering students in English class. The analysis of the participants' responses was based directness categories of request strategies proposed by Blum-Kulka \& Olsthain in Mohamed (2019).

Table 2. Categories of directness of request strategies

\begin{tabular}{llllllll}
\hline \multirow{2}{*}{ DCT } & \multicolumn{2}{c}{ Direct Strategy } & \multicolumn{2}{c}{$\begin{array}{c}\text { Conventional } \\
\text { Indirect Strategy }\end{array}$} & \multicolumn{2}{c}{$\begin{array}{c}\text { Non-Conventional } \\
\text { Indirect Strategy }\end{array}$} & $\begin{array}{c}\text { Total } \\
\text { students }\end{array}$ \\
\cline { 2 - 6 } & Class A & Class B & Class A & Class B & Class A & Class B & \\
\hline S1 & 10 & 5 & 9 & 9 & - & 4 & 37 \\
S2 & - & 10 & 15 & 7 & 4 & 1 & 37 \\
S3 & 5 & 7 & 12 & 10 & 2 & 1 & 37 \\
S4 & 5 & 8 & 9 & 6 & 5 & 4 & 37 \\
S5 & 2 & 1 & 13 & 15 & 4 & 2 & 37 \\
Frequency & 23 & 31 & 60 & 47 & 12 & 12 & 185 \\
Percentage & 12.4 & 16.8 & 32.4 & 25.4 & 6.5 & 6.5 & $100 \%$ \\
\hline
\end{tabular}

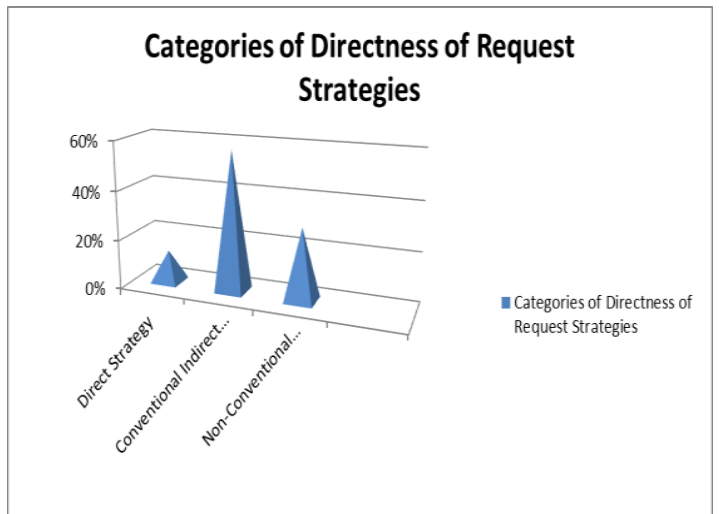

Figure 1. Categories of directness of request strategies 
The findings show that $57 \%$ or 107 out of 185 Industrial Engineering students' responses mostly use conventional indirect strategies, $29.2 \%$ or 44 responses are direct strategies, and $13 \%$ or 24 responses belong to non-conventional indirect strategies.

Most of the responses in all situations related to social distance, level of power, and level of imposition, are indirect both conventional and non-conventional strategies. Cultural background influences much the way Indonesians communicate each other in their daily conversation. The learners of English as a foreign language in Indonesia tend to express their request indirectly since the characteristics of Indonesians do not convey their ideas explicitly. In High context culture such as Indonesia the purpose of communication is to maintain and strengthen the relationships by minimizing the hearer's face threat. The use of indirect also request ensures the harmony within the speaker and the hearer in high context culture. Non-verbal behavior involves in any communication to hide negative comments. It is not what is said with words but how it is said and expressed.

By using $70 \%$ of indirect strategies in making requests, Industrial Engineering students in Universitas Pancasakti Tegal seem to trust the non-verbal messages more, rather than the words used as mentioned previously as one of characters of high context culture. They tend to not expressing a clear request for saving face of both speaker and the hearer. Indirect strategies or by not saying something directly is indicating politeness, especially when the speaker considers $\mathrm{him} /$ herself powerless compared to the hearer as Chiravate in Sukarno (2018) stated that request is proposing someone to perform something which is rewarding to the speaker but costly to the hearer, and therefore politeness strategies are employed. The purpose of indirect strategies used by Industrial engineering students are mostly to keep the communication stay in harmony by minimizing imposition or face threatening act whereas nearly $30 \%$ of direct strategies usage occurs when the speaker considers that his/her power is equal to that of the hearer's, the speaker tends to use direct strategy in posing requests. This may be due to the fact that there is less risk of threatening the face of the hearer as in the situation 3 .

The use of indirect strategy in making request is contradictory with in low context culture. Low context communication runs very differently to high context communication systems. Lowcontext cultures lean to stress logic and rationality, based on an objective truth that can be reached through linear processes of discovery. Cross-cultural studies indicate that people raised in Western cultures would rather have global rules than those raised in Eastern cultures such as Indonesia. Norenzayan et al. (2002) stated that western preferred to characterize based on formal rules, whereas Eastern decided based on family resemblance. Therefore, the hearer comprehends the message clearly minimizing misunderstanding especially in cross-cultural communication.

\section{Nine sub-levels of request strategy}

The nine sub-levels of request strategy types form a scale of indirectness. Direct level has five sub level categories, mood derivable, explicit perfomative, obligation statement, and want statement. The next two belong to the conventional indirect level, they are suggestive formulae, and query preparatory. The last two are the non-conventional indirect level; strong hints, and mild hints.

Table 3. Nine sub-levels of request strategy

\begin{tabular}{|c|c|c|c|c|c|c|}
\hline No & & Descriptive Categories & Class A & Class B & Frequency & Percentage \\
\hline 1. & Direct & Mood Derivable & & 3 & 3 & 1.6 \\
\hline 2. & Strategies & Explicit Performative & 12 & 21 & 33 & 17.8 \\
\hline 3. & & Hedged Performative & & & & \\
\hline 4. & & Obligation statement & & & & \\
\hline 5. & & Want Statement & 13 & 6 & 19 & 10.3 \\
\hline 6. & $\begin{array}{l}\text { Conventional } \\
\text { ly indirect }\end{array}$ & Suggestive Formulae & 6 & 3 & 9 & 4.9 \\
\hline 7. & strategies & Query Preparatory & 48 & 44 & 92 & 49.7 \\
\hline 8. & Non- & Strong Hints (A) & 11 & 6 & 17 & 9.2 \\
\hline 9. & Conventional & Mild Hints (B) & 5 & 7 & 12 & 6.5 \\
\hline
\end{tabular}




\begin{tabular}{lcccc}
$\begin{array}{l}\text { ly indirect } \\
\text { strategies }\end{array}$ & & & & \\
\hline Total Responses & 95 & 90 & 185 & $100 \%$ \\
\hline & & & & (Blum-Kulka, 1987)
\end{tabular}

The findings show that query preparatory is used most significantly and mood derivable constitutes the least frequently used in making request. The table shows that $49.7 \%$ or 92 out of 185 responses belong to query preparatory. 17.8 $\%$ or 33 responses are identified as explicit performatives, $10.3 \%$ or 19 responses categorized as want statements, $9.2 \%$ or 17 responses classified as strong hints, $6.5 \%$ or 12 responses grouped as mild hints, $4.9 \%$ or 9 responses recognized as suggestive formulas, and $1.6 \%$ or 3 responses indicated as mood derivable. The following is a further explanation of the examples of each sub-level of request strategy.

The following request in situation 1 is conventional indirect strategy belong to query preparatory: today?"

"Excuse me, sir. May I have a make-up test for

The example of conventional indirect strategy belongs to suggestive formulae in situation 2 .

"How about doing physics assignment tomorrow?"

The speaker's indirect requests to the hearer of higher or superior status (situation 1) and of equal status (situation 2) indicate that she or he is trying to save his or her own face and the hearer's. It is the way for the speaker to minimize the imposition by employing indirect strategies rather than direct ones. By minimizing the imposition on the hearer, the speaker is avoiding the embarrassment on the hearer or even selfembarrassment. The desired goal of communication may not be reached but it can maintain their good interpersonal relationship by making appropriate request.

The example of a request strategy in situation 3 belongs to direct strategy want statement:

"Hi, I want to meet you."

Direct strategy belongs to explicit performative in situation 4 .

"Mom, I ask for money to pay the semester test."

The speaker's direct requests to the hearer of equal status (situation 3) and of superior status (situation 4) are clear, and brief. Its illocutionary purpose is to get the hearer to do something. The more transparent it is the less of a burden the hearer bears in interpreting the request. The direct request made is surprising, as people of high context culture such as Indonesians tend to use some more complex means of persuasion rather than simply asking.

Non-conventional indirect strategy belongs to mild hints in situation 5 .

"Excuse me, sir. The hospital is on the Buqeinville Street closed to the bank."

The speaker's request to the stranger implies indirectness. The speaker wants to put imposition on the hearer to show the direction to the hospital. The use of indirectness implicitly gives small burden on the hearer the pleasure to perform the speaker's need. The mild hints used lightly state the recent situation of being in need of showing direction. In this situation, the speaker troubled the hearer less to do the speaker's intention.

Non-conventional indirect strategy belongs to strong hints in situation 4.

"Mom today is the last day to pay."

The indirectness shows the strong hints to a person of superior status the last day to pay university tuition. The utterance has partial reference to object for the implementation of the act and intents to impose more on the reference by using gentle reprimand 'the last day' to show respect and politeness to the person of superior status 'his/her mom.' To mitigate or soften the effect of speech acts, speaker may choose to state their utterances indirectly. Indirect requests can be intended to save face and to show respect, particularly in Indonesian cultures. Face-saving can be the speakers' intention to maintain the relationship such as in Indonesian cultures (social utility; Yoon, Tessler, Goodman, \& Frank, 2016). A speaker with a high weight on social utility will try to save her listener's face: She hides or risks losing information in her intended message by making her utterance false to some degree.

Direct strategy belongs to mood derivable in situation 2.

"Go home, do group assignment, please.'

The grammatical mood of the verb in the utterance marks its illocutionary force as request. The speaker uses direct strategy to convey the message reducing the occurrence of misapprehension. When the request is clearly stated, the objective of the communication will be simply achieved.

The other findings also show that request perspectives categories frequently used by students is hearer oriented and the syntactic 
downgrader mostly used is interrogative frequently to show indirectness and politeness:

Situation 1: "May I meet you tomorrow?'

Situation 2: "Can you help me doing assignment?'

Situation 3: 'Would you meet me at Alun-alun Tegal to night?"

Situation 4: "Mom, can I have money fro semester test?"

Situation 5: "Can you show me the direction to the hospital around here?"

\section{CONCLUSION}

Indirectness are mostly used by Indonesian EFL learners in response to the given situations regardless social distance, level of power, and level of imposition. They are conventional indirect strategies and non-conventional. The indirectness is greatly influenced by students' cultural background, which belong to highcontext culture. The use a lot of unspoken information is used to place a larger importance on long-term relationships and loyalty. People in high context culture such as the students of Universitas Pancasakti Tegal refer to the value cultures placing on indirect communication. Communication occurs by relying much on cultural information background and non-verbal behavior. A message is understood with a great deal of gesture, facial expressions, tone of voice, eye contact, body language, posture, and other ways people can communicate without using language. It sometimes causes misunderstanding during the communication therefore providing clarification is needed if the communication does not run well. Understanding what the speaker intends fully, a listener must employ their ability to "read between the lines."

The finding of the current study has implications for English teachers in all educational setting, especially at university level in recognizing the strategies used by Engineering students of Universitas Pancasakti Tegal. The finding can be used for EFL learners to enrich their pragmatic knowledge, and crosscultural understanding to avoid communication breakdowns, since learners will aware more the differences in using request strategy and noticing the FTA.

Industrial Engineering students of Universitas Pancasakti Tegal do not represent all EFL learners in Indonesia. They are not homogeneous in English competency, which may have some effects on the results of this study therefore further studies need to expose EFL learners to various types of request strategies in the different situations.

\section{REFERENCES}

Al Aamri, R. (2014). Teaching speech acts to EFL college-level Omani learners: Requests and refusals (Unpublished master's thesis). Wisconsin: University of Wisconsin-River Falls.

Anhangari, S., \& Shoghli, M. (2011). Investigating request strategies between Iranian EFL learners and Canadian native speakers of English in various social situations. International Conference on Languages, Literature and Linguistics IPEDR vol.26, Singapore: IACSIT Press.

Amer, F., Buragohain, D., \& Suryani, I. (2020). Politeness strategies in making requests in Jordanian call-centre interactions. Education and Linguistics Research, 6(1), 69-86. doi: 10.5296/elr.v6i1.16283.

Bitterlin, G., Johnson, D., Price, D., Ramirez, S., \& Savage, L. (2008). Ventures. Cambridge: Cambridge University Press.

Brown, J. D. (2008). Raters, functions, item types and the dependability of L2 pragmatics tests. In E. Alcón Soler \& A. Martínez-Flor (Eds.), Investigating pragmatics in foreign language learning, teaching and testing (pp. 213-219). Bristol, England: Multilingual Matters.

Choe, Y. (2005). Intercultural conflict patterns and intercultural training implications for Koreans. International Area Studies Review, 5, 111-128. doi: 10.1177/223386590200500106.

Cohen, A. (2010). Coming to terms with pragmatics. In N. Ishihara, \& A. Cohen (Eds.), Teaching and learning pragmatics: Where language and culture meet (pp. 3-21). London: Pearson.

Daskalovska, N., Ivanovska, B., Kusevska, M., \& Ulanska, T. (2016). The use of request strategies by EFL learners. Procedia - Social and Behavioral Sciences, 232, 55-61.

Derakhshan, A., \& Arabmofrad, A. (2108). The impact of instruction on the pragmatic comprehension of speech acts of apology, request, and refusal among Iranian intermediate EFL learners. English Teaching \& Learning 42, 75-94 (2018). doi: 10.1007/s42321-018-0004-6.

Devecia, T \& Hmida, I. B. (2017). The request speech act in emails by Arab university students in the UAE. Journal of Language and Linguistic Studies, 13(1), 194-214.

Guest, M. (2009). Is English really low-context? The Daily Yomiuri. Tokyo; Japan.

Herget, K., \& Pérez, N. (2019). Analysis of the speech act of request in the foreign language classroom. 5th International Conference on Higher Education Advances (HEAd'19) Universitat Polit'ecnica de Val'encia, Val’encia, doi: 10.4995/HEAd19.2019.9097.

Holliday, A., Hyde, M., \& Kullman, J. (2010). Intercultural communication: An advanced resource book for students. New York: Routledge.

Hussein, N., \& Albakri, I. (2019). The importance of the speech act of request in the Iraqi EFL 
ENGLISH REVIEW: Journal of English Education

Volume 8, Issue 2, June 2020

classroom. International Journal of English Research 5(2), 95-98.

Hussein, N., \& Albakri, I. (2019). The role of strategies on developing Iraqi learners' usage of request in EFL classroom. International Journal of English, Literature and Social Science, 4(5), 1337-1341.

Jalilifar, A. (2009). Request strategies: Cross-sectional study of Iranian EFL learners and Australian native speakers. English Language Teaching, 2(1), 46-61.

Liu, X., \& Allen, T.J. (2014). A study of linguistic politeness in Japanese. Open Journal of Modern Linguistics, 4, 651-663.

McCarthy, M., McCarten, J. \& Sandiford, H. (2014). Touchstone (2nd ed.). Cambridge: Cambridge University Press.

McNamara, T. F., \& Roever, C. (2006). Language testing: The social dimension. Oxford, UK: Basil Blackwell.

Mitkovska, L., Kusevska, M., \& Buzarovska, E. (2013). Corpus investigations of the English interlanguage of Macedonian learners. Skopje: FON University.

Mohamed, H. (2019). Request strategies and level of request directness in Moroccan Arabic and American English. IOSR Journal of Humanities And Social Science, 24(8), 10-20.

Norenzayan, A., Smith, E. E., Kim, B. J., \& Nisbett, R. E. (2002). Cultural preferences for formal versus intuitive reasoning. Cognitive Science, 26, 653-684.

Soars, J., \& Soars, L. (2010). American headway (2nd ed.). Oxford: Oxford University Press.

Sukarno. (2018). Politeness strategies, linguistic markers and social contexts in delivering requests
p-ISSN 2301-7554, e-ISSN 2541-3643

https://journal.uniku.ac.id/index.php/ERJEE

in Javanese. Indonesian Journal of Applied Linguistics, 7(3), 659-667.

Saadatmandi, M., Modarres, S., \& Pourdana, K. N. (2018). Teaching English pragmatic features in EFL context: A focus on request speech acts. Theory and Practice in Language Studies, 8(7) 829-835. doi: 10.17507/tpls.0807.14.

Vásquez, C., \& Sharpless, D. (2009). The role of pragmatics in the master's TESOL curriculum: Findings from a nationwide survey. TESOL Quarterly, 43(1), 5-28.

Wichmann, A. (2004). The intonation of pleaserequest: A corpus-based study. Journal of Pragmatics, 36, 1521-1549. doi: 10.1016/j.pragma.2004.03.003.

Yazdanfar, S., \& Bonyadi, A. (2016). Request strategies in everyday interactions of Persian and English speakers. SAGE Open October-December: 1-11. doi: $10.1177 / 2158244016679473$.

Yoon, E. J., Tessler, M. H., Goodman, N. D., \& Frank, M. C. (2016). Talking with tact: Polite language as a balance between kindness and informativity. Proceedings of the thirty-eighth annual conference of the Cognitive Science Society.

Zarepour, F. (2016). An analysis of Iranian EFL learners' English written requestive e-mails. Journal of Language Teaching and Research, 7(3), 579-585.

Zhang, C. (2019). A study on politeness principle of intercultural communication of HCC and LCC. Advances in Social Science, Education and Humanities Research, $345 . \quad$ Conference: Proceedings of the 2019 3rd International Seminar on Education, Management and Social Sciences (ISEMSS 2019). doi: 10.2991/isemss19.2019.141. 
Yoga Prihatin \& Nur Aflahatun

The use of request strategies of industrial engineering students 